\title{
HPTLC and RP-HPTLC Method Development and Validation for the Estimation of Felodipine in Bulk and Pharmaceutical Formulation
}

Jain PS*, Ansari NA and Surana SJ

R. C. Patel Institute of Pharmaceutical Education and Research, Karwand Naka, India

\begin{abstract}
The aim of this work is to establish developed and validated method for the pharmaceutical analysis of Felodipine in bulk and pharmaceutical formulation by High Performance Thin Layer Chromatography HPTLC (NP) and Reverse Phase-High Performance Thin Layer Chromatography RP-HPTLC (RP). Chromatographic separation was performed on Pre-coated aluminum plates with $250 \mu \mathrm{m}$ layer of Silica gel $60 \mathrm{~F}_{254}$ and Silica gel $60 \mathrm{RP}-18 \mathrm{TLC}$ $\mathrm{F}_{254} \mathrm{~S}$ using Toluene: Methanol $(8: 2 \mathrm{v} / \mathrm{v})$ and acetonitrile: water: glacial acetic acid $(8: 2: 1 \mathrm{v} / \mathrm{v} / \mathrm{v})$ as a mobile phase, respectively. Scanning was carried out densitometrically at $237 \mathrm{~nm}$. The $R_{f}$ value of Felodipine in NP and RP were 0.40 and 0.53 and the reliability of the method was assessed by the evaluation of linearity which was found to be $300-1800$ and $500-3000 \mathrm{ng} / \mathrm{band}$ with the $\mathrm{r}^{2}=0.998$ correlation coefficient along with the accuracy of the method in terms of \% recovery was found to be from $98-101 \pm 1.04 \%$ and $99-100 \pm 0.47 \%$ and the limit of detection and quantification were $11.51,34.90$ and $29.90,90.61$, respectively. The method can be used for routine analysis of Felodipine in bulk and pharmaceutical formulation.
\end{abstract}

Keywords: Felodipine (FDP); TLC; Densitometry; Validation

\section{Introduction}

Felodipine (FDP) is chemically known as 4-(2, 3-Dichlorophenyl)-1, 4-dihydro-2, 6-dimethyl-3, 5 pyridinedicarboxylic acid ethyl methyl ester (Figure 1). The molecular formula is $\mathrm{C}_{18} \mathrm{H}_{19} \mathrm{Cl}_{2} \mathrm{NO}_{4}$ This corresponds to a molecular weight of $384.3 \mathrm{gm} \mathrm{[1].} \mathrm{It} \mathrm{is} \mathrm{a}$ dihydropyridine calcium channel blocker used mainly for the management of hypertension and angina pectoris like the other calcium channel blockers [2]. Being a dihydropyridine derivative, FDP has the advantages of being a more selective vasodilator and having less cardiac effects than non-dihydropyridine calcium antagonists [3].

In the literature survey analytical methods have been reported for the estimation of Felodipine which include capillary gas chromatography [4], RP-HPLC [5-8], Stability-Indicating RPHPLC $[9,10]$, Micellar liquid chromatography [11], LC-MS [12], Spectroscopy [13-15], HPLC in rabbit plasma and pig serum [16,17].

The aim of this work is to established simple, precise, sensitive and effective RPy HPTLC and RP-HPTLC in Bulk and Pharmaceutical Formulation. The method was validated as per ICH guidelines.

\section{Experimental}

\section{Chemical and reagents}

Felodipine (Pure) were obtained as a gift sample from Glenmark Pharmaceutical Ltd., Mumbai. All chemicals and reagents were used of HPLC grade and were purchased from Merck Chemicals, India.

\section{HPTLC instrumentation}

The High Performance Thin layer Chromatography (HPTLC) system (Camag Switzerland) having Camag Linomat 5 applicator with Camag TLC Scanner 3, Camag twin trough developing chambers (20 $\times 10 \mathrm{~cm}$ ), Camag UV Cabinet with dual wavelength UV lamps (254 and $366 \mathrm{~nm})$, Camag Hamilton micro syringe $(100 \mu \mathrm{L})$, Pre-coated aluminum plates with $250 \mu \mathrm{m}$ layer of Silica gel $60 \mathrm{~F}_{254}$ and Silica gel 60 RP-18 TLC $\mathrm{F}_{254} \mathrm{~S}$ and Electronic analytical balance Shimadzu AUX-120 was used for all the weighing.

\section{Chromatographic conditions}

Chromatographic separation was performed on $20 \times 10 \mathrm{~cm}$ precoated aluminum plates with $250 \mu \mathrm{m}$ layer of silica gel $60 \mathrm{~F}_{254}$ and Silica gel 60 RP-18 TLC $F_{254}$ S (E. Merck, Darmstadt, Germany) for NP and RP, respectively. The plates were prewashed with methanol and activated at $100^{\circ} \mathrm{C}$ for 10 minutes prior to the application. Sample was spotted in the form of $6 \mathrm{~mm}$ width with the help of Camag Hamilton micro syringe $(100 \mu \mathrm{L})$ on TLC plate from the bottom edge using Linomat 5 applicator. The TLC plate was developed in twin trough developing chamber using Toluene: Methanol (4:1 v/v) for NP and acetonitrile: water: glacial acetic acid $(4: 1: 0.3 \mathrm{v} / \mathrm{v} / \mathrm{v})$ for $\mathrm{RP}$, as mobile phase at room temperature $\left(25^{\circ} \mathrm{C} \pm 2^{\circ} \mathrm{C}\right)$ with the 20 minutes of chamber saturation up to the $80 \mathrm{~mm}$ development distance. Densitometry scanning was<smiles>CCOC(=O)C1=C(C)NC(C)=C(C(=O)OC)C1c1cccc(Cl)c1Cl</smiles>

*Corresponding author: Pritam S Jain, R. C. Patel Institute of Pharmaceutical Education and Research, Karwand Naka, India, Tel: +91-7620227021; Fax: +912563251808; E-mail: pritash79@yahoo.com

Received October 08, 2018; Accepted November 12, 2018; Published November 19,2018

Citation: Jain PS, Ansari NA, Surana SJ (2018) HPTLC and RP-HPTLC Method Development and Validation for the Estimation of Felodipine in Bulk and Pharmaceutical Formulation. Pharm Anal Acta 9: 599. doi: 10.4172/2153-2435.1000599

Copyright: (c) 2018 Jain PS, et al. This is an open-access article distributed under the terms of the Creative Commons Attribution License, which permits unrestricted use, distribution, and reproduction in any medium, provided the original author and source are credited. 
performed at $237 \mathrm{~nm}$ on a Camag TLC scanner 3 and was operated by winCATS software version 1.3.0.

\section{Preparation of standard stock solution}

An accurately weighed $50 \mathrm{mg}$ of Felodipine (FDP) was transferred into a $50 \mathrm{~mL}$ volumetric flask, dissolved in methanol and volume made up to the mark with the same solvent to achieve $1000 \mathrm{ng} / \mu \mathrm{L}$.

\section{Method Validation}

\section{Linearity}

Linearity was performed using working standard stock solution of FDP in the range of 300-1800 $\mathrm{ng} / \mathrm{spot}$ and $500-3000 \mathrm{ng} / \mathrm{spot}$ by applying $0.3-1.8$ and $0.5-3.0 \mu \mathrm{L}$, for NP and RP, respectively.

\section{Analysis of tablet formulation}

To determine the amount of Felodipine in tablets (Felogard ER$10 \mathrm{mg} /$ tablet); twenty tablets were accurately weighed and finely powdered. An amount equivalent to $10 \mathrm{mg}$ from tablets powder were transferred into $10 \mathrm{~mL}$ volumetric flask and extracted with methanol by shaking mechanically for $15 \mathrm{~min}$ and volume was made up to the mark and filtered using $0.41 \mu \mathrm{m}$ filter (Millifilter, Milford, MA). From the above solution 900 and $1500 \mathrm{ng} /$ spot were applied for NP and RP, respectively.

\section{Accuracy}

Accuracy was determined in terms of \% recovery. Recovery study of FDP was carried out by over spotting of the known amount of the standard FDP in the sample at $80 \%, 100 \%$ and $120 \%$ level for both methods. The total concentration of the drug was determined. At each level three determinations were performed.

\section{Precision}

Precision of the method was estimated as intra-day and inter-day changes by analyzing 600, 900, 1200 and 1000, 1500 and $2000 \mathrm{ng} / \mathrm{spot}$ in triplicate on the same day for three times for intra-day precision and three consecutive days for the inter-day precision for NP and RP, respectively.

\section{Limit of detection (LOD) and Limit of quantification (LOQ)}

Detection limit and Quantification limit was calculated by the RPased on the SD of the response and the slope of the calibration curve. Sensitivity of the proposed method was estimated as per ICH guidelines in terms of limit of detection $\mathrm{LOD}=3.3 \times \sigma / \mathrm{S}$ and $\mathrm{LOQ}=10 \times \sigma / \mathrm{S}$, where, $\sigma$ is the standard deviation and $S$ is the slope.

\section{Specificity}

The specificity of the method was determined by analyzing standard drug and tablet formulation. The spot of the FDP in the tablet formulation was confirmed by comparing the $\mathrm{R}_{f}$ value and the spectra with respect to standard drug. The peak purity was assessed at three different level i.e., peak start $(S)$, peak apex $(M)$ and peak end $(E)$ positions of the spot.

\section{Robustness}

Robustness of the method was performed by spotting 900 and 1500 ng/spot of FDP for NP and B on TLC plate by making small deliberate changes in the chromatographic conditions to examine the effects on the results by performing the parameters include mobile phase composition, development distance, activation of plate and duration of chamber saturation.

\section{Result and Discussion}

\section{Development of optimum mobile phase}

Different ratio of toluene: Methanol for NP and acetonitrile: water for RP was tried as a mobile phase but different errors was observed such as tailing of spot, less persistence and spreading of spots. In order to overcome the problems, toluene: methanol $(8: 2 \mathrm{v} / \mathrm{v})$ and acetonitrile: water: glacial acetic acid $(8: 2: 1 \mathrm{v} / \mathrm{v} / \mathrm{v})$ was tried and results observed in good resolution, sharp and symmetrical peak with $\mathrm{R}_{f} 0.40$ (Figure 2) $\mathrm{NP}$ and 0.53 (Figure 3) RP. It was observed after prewashing of TLC with methanol (followed by drying and activation) and pre-saturation of chamber with mobile phases for $20 \mathrm{~min}$.

\section{Linearity}

The linear regression data for the calibration curve of FDP by NP and B was determined in the concentration range of 3001800 and 500-3000 ng/spot with the Linear regression equation $\mathrm{Y}=4.4713 \mathrm{x}+813 \quad\left(\mathrm{r}^{2} 0.998\right) \quad$ and $\mathrm{Y}=3.2239 \mathrm{x}+968 \quad\left(\mathrm{r}^{2} 0.998\right)$ correlation coefficient. The calibration curve shown in Figures 4 and 5 and the 3-D linearity chromatogram is shown in Figures 6 and 7 , respectively.

\section{Analysis of tablet formulation}

A single spot at $\mathrm{R}_{f} 0.40$ and 0.53 was observed for $\mathrm{NP}$ and $\mathrm{B}$ in the chromatogram of FDP. There was no interference from the excipients commonly present in the tablet. The \%drug content and \%RSD were calculated. The low $\%$ RSD value indicated the suitability of this method for the routine analysis of Felodipine in pharmaceutical dosage forms. Results are discussed in Table 1.

\section{Recovery study}

The proposed methods when used for extraction and subsequent estimation of FDP from the pharmaceutical dosage form after over spotting with 80,100 and $120 \%$ of additional drug for both methods mean recovery is within acceptable limit. The \% recovery listed in Table 2 .

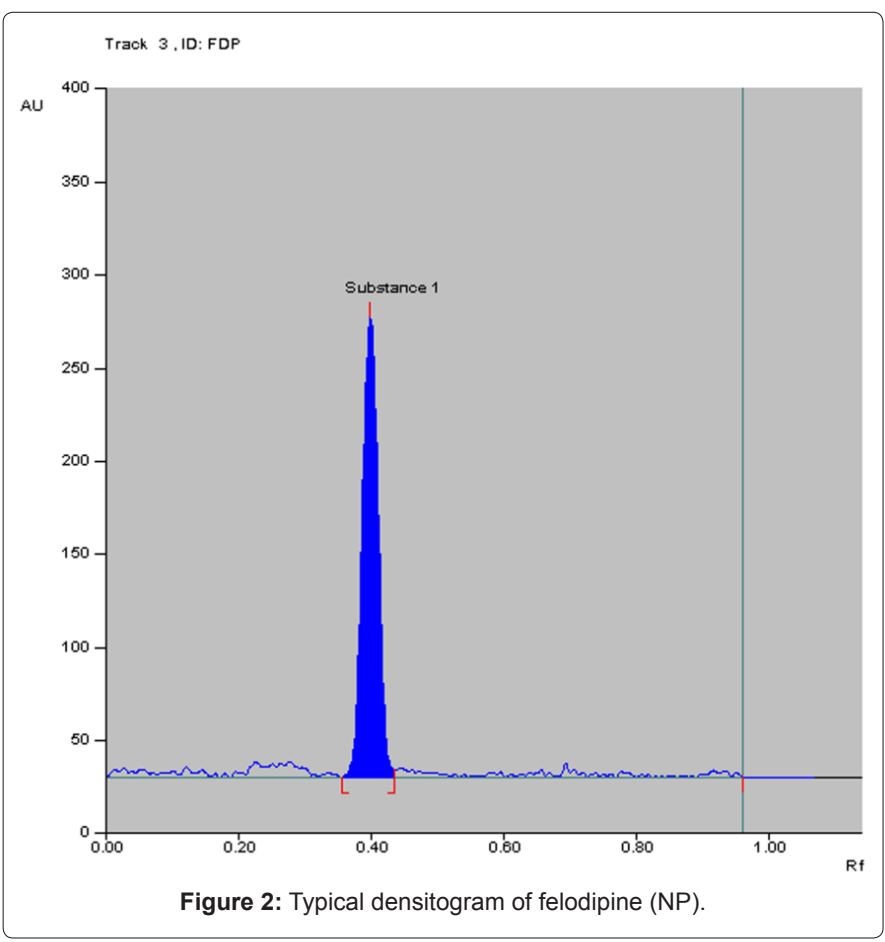


Citation: Jain PS, Ansari NA, Surana SJ (2018) HPTLC and RP-HPTLC Method Development and Validation for the Estimation of Felodipine in Bulk and Pharmaceutical Formulation. Pharm Anal Acta 9: 599. doi: 10.4172/2153-2435.1000599

Page 3 of 6
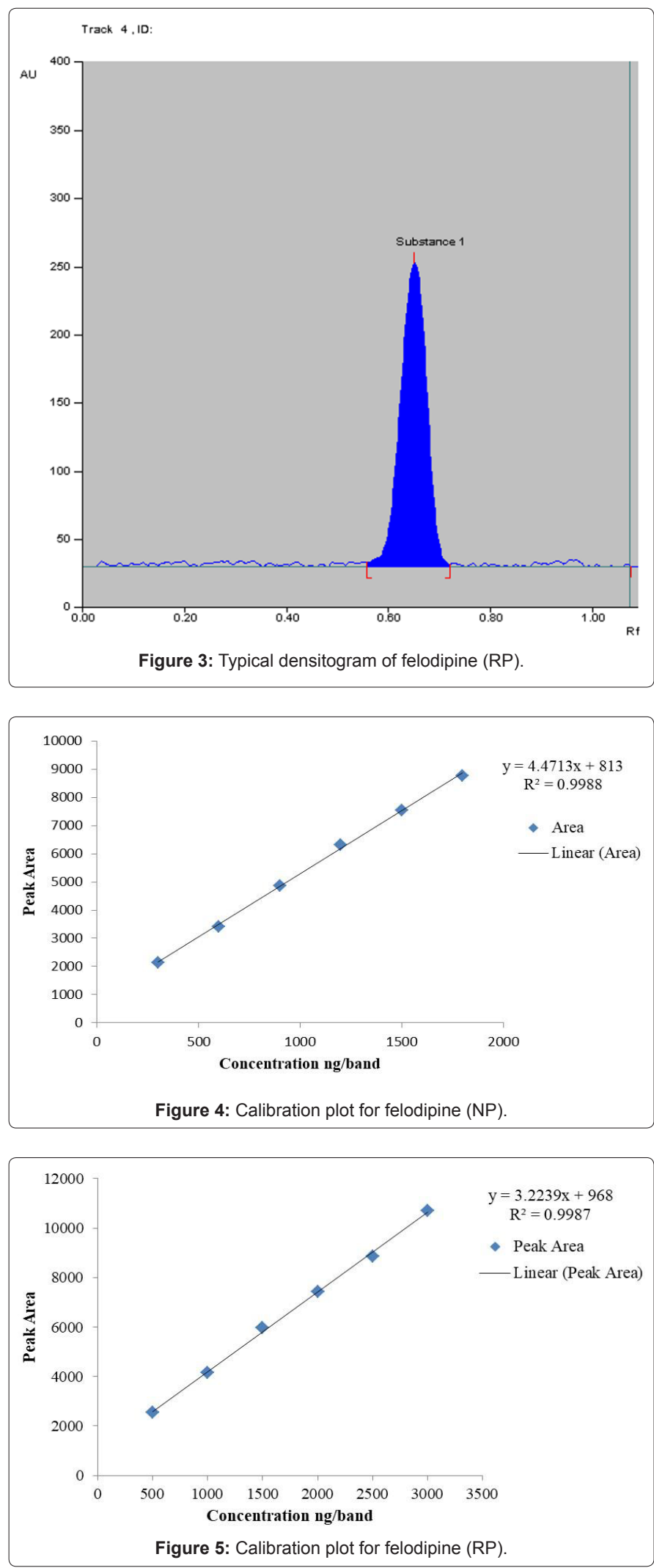

\section{Precision}

The precision of the proposed method was estimated in terms of $\%$ relative standard deviation (\%RSD). The results depicted revealed high precision of the method is presented in Table 3.

\section{Limit of detection (LOD) and Limit of quantification (LOQ)}

Sensitivity of the developed method was determined in terms of limit of detection (LOD) and limit of quantification (LOQ) for FDP. The LOD and LOQ of NP is 11.51 and 34.90 and RP was found to be 29.90 and 90.61 , respectively. This indicates the adequate sensitivity of the method.

\section{Specificity}

The peak purity of FDP was assessed in NP and B by comparing the spectra at three levels, i.e. peak start (S), peak apex (M) and peak end (E) position of the spot and the result obtained for $\mathrm{NP}$ as $\mathrm{r}^{2}(\mathrm{~S}, \mathrm{M})=0.999$, $r^{2}(M, E)=0.998$ and for $R P$ as $r^{2}(S, M)=0.999, r^{2}(M, E)=0.998$. Good correlation was obtained between standard and sample spectra of FDP (Figures 8 and 9).

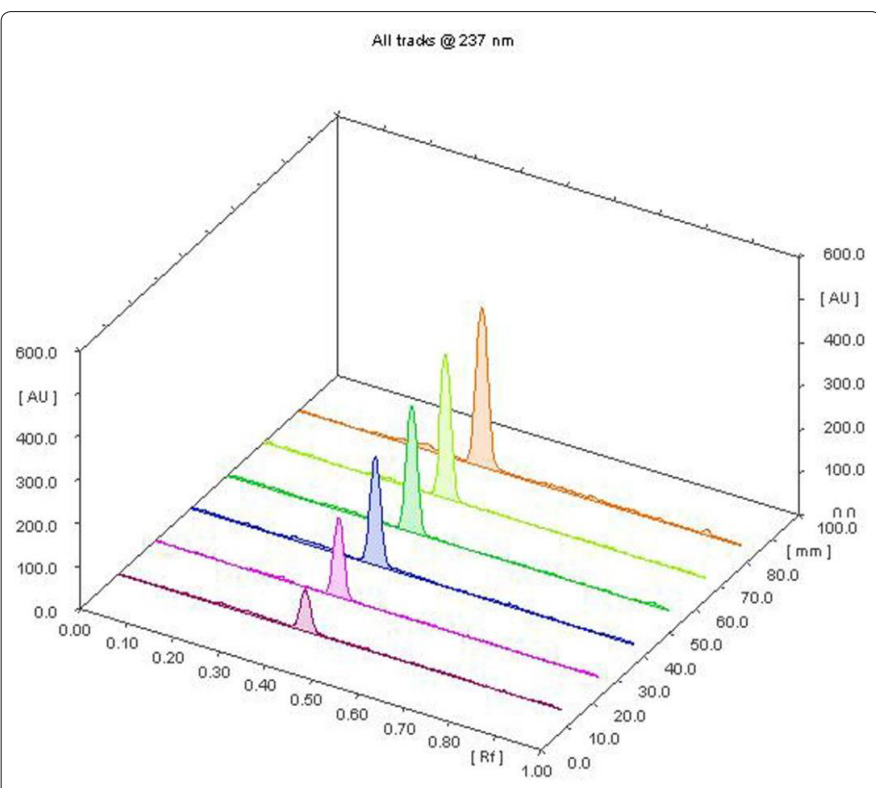

Figure 6: Three dimension TLC chromatogram showing FDP linearity (NP).

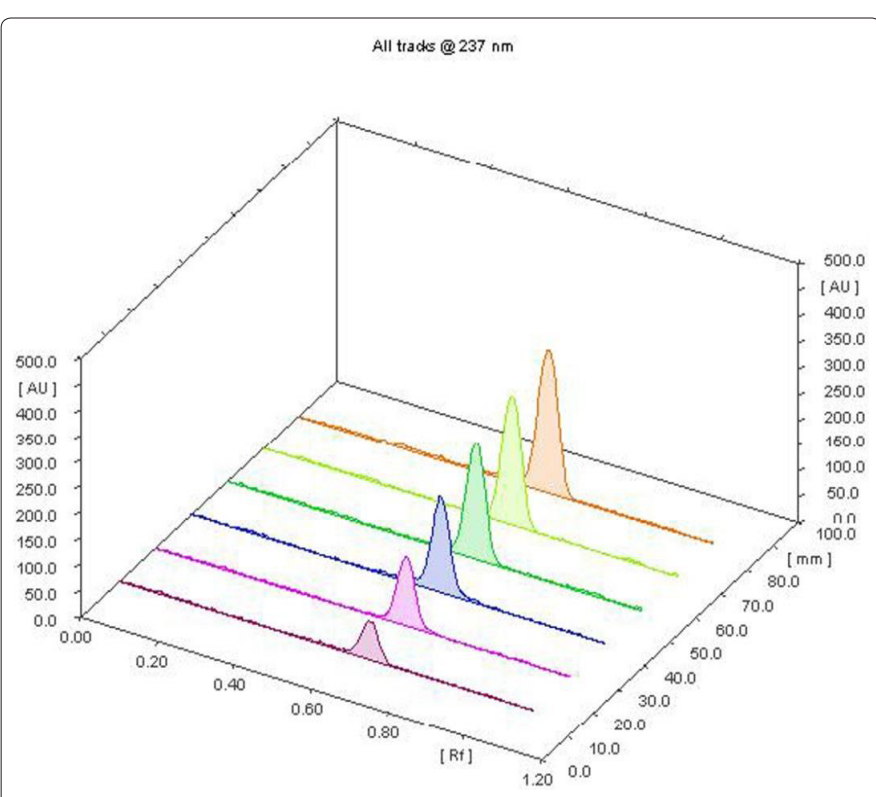

Figure 7: Three dimension TLC chromatogram showing FDP linearity (RP). 
Citation: Jain PS, Ansari NA, Surana SJ (2018) HPTLC and RP-HPTLC Method Development and Validation for the Estimation of Felodipine in Bulk and Pharmaceutical Formulation. Pharm Anal Acta 9: 599. doi: 10.4172/2153-2435.1000599
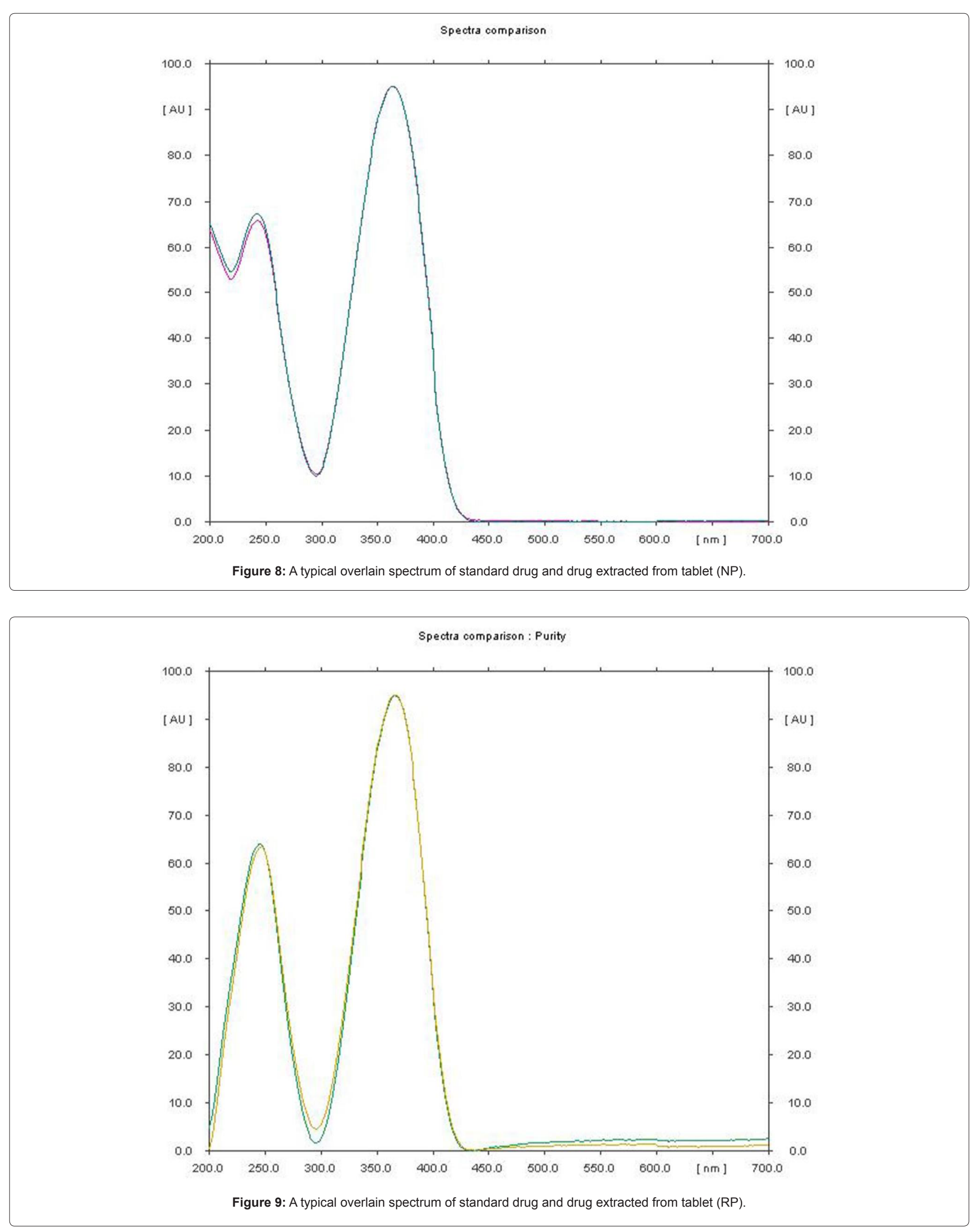
Citation: Jain PS, Ansari NA, Surana SJ (2018) HPTLC and RP-HPTLC Method Development and Validation for the Estimation of Felodipine in Bulk and Pharmaceutical Formulation. Pharm Anal Acta 9: 599. doi: 10.4172/2153-2435.1000599

Page 5 of 6

\begin{tabular}{|c|c|c|c|c|}
\hline Method & \multicolumn{2}{|c|}{ NP } & \multicolumn{2}{c|}{ RP } \\
\hline \multirow{2}{*}{ Felogard ER 10mg/tab. } & \% Drug Content \pm SD & $\%$ RSD & \% Drug Content \pm SD & $\%$ RSD \\
\cline { 2 - 5 } & $99.07 \pm 1.52$ & 1.53 & $99.74 \pm 1.25$ & 1.25 \\
\hline
\end{tabular}

Table 1: Analysis of tablet formulation.

\begin{tabular}{|c|c|c|c|c|c|}
\hline \multirow{2}{*}{ Label Claim (mg/tablet) } & \multirow{2}{*}{ Level of recovery } & *Drug Recovered \pm SD & \multicolumn{2}{c|}{ \% RSD } \\
\cline { 2 - 6 } & & NP & RP & NP & 0.0814 \\
\hline \multirow{3}{*}{10} & 80 & $98.95 \pm 97.08$ & $99.92 \pm 5.51$ & 0.7276 & 0.7745 \\
\cline { 2 - 6 } & 100 & $98.46 \pm 55.29$ & $98.79 \pm 57.13$ & 0.5111 & 0.5673 \\
\cline { 2 - 6 } & $100.23 \pm 34.36$ & $99.75 \pm 45.67$ & \\
\hline
\end{tabular}

Table 2: Recovery study.

\begin{tabular}{|c|c|c|c|c|c|c|c|c|c|}
\hline \multirow{2}{*}{\multicolumn{2}{|c|}{ Conc.( ng/spot) }} & \multicolumn{4}{|c|}{ Intra-day ${ }^{*}$} & \multicolumn{4}{|c|}{ Inter-day* } \\
\hline & & \multicolumn{2}{|c|}{$\%$ Amount found \pm SD } & \multicolumn{2}{|c|}{$\%$ RSD } & \multicolumn{2}{|c|}{$\%$ Amount found \pm SD } & \multicolumn{2}{|c|}{$\%$ RSD } \\
\hline NP & RP & NP & RP & NP & RP & NP & RP & NP & RP \\
\hline 600 & 1000 & $99.0589 \pm 2.0616$ & $99.9627 \pm 6.0976$ & 0.3468 & 0.6099 & $99.5087 \pm 1.1692$ & $99.6479 \pm 5.4186$ & 0.1958 & 0.543 \\
\hline 900 & 1500 & $100.3312 \pm 4.0753$ & $99.6450 \pm 2.8135$ & 0.4513 & 0.1882 & $100.5756 \pm 7.1513$ & $99.9155 \pm 1.1020$ & 0.7900 & 0.0735 \\
\hline 1200 & 2000 & $100.0778 \pm 3.3297$ & $99.9976 \pm 19.3978$ & 0.2772 & 0.9699 & $100.5670 \pm 8.1933$ & $100.0980 \pm 12.2309$ & 0.6789 & 0.6109 \\
\hline
\end{tabular}

Table 3: Precision.

\begin{tabular}{|c|c|c|c|c|c|}
\hline \multicolumn{2}{|c|}{ Parameters } & \multicolumn{2}{c|}{ \pm SD of Peak area* } & \multicolumn{2}{c|}{ \%RSD } \\
\cline { 3 - 6 } & & NP & RP & 2.00 & RP \\
\hline \multirow{2}{*}{ Mobile Phase composition } & $-1.0 \mathrm{~mL}$ & 93.01 & 97.15 & 1.61 & 1.74 \\
\cline { 2 - 6 } & $+1.0 \mathrm{~mL}$ & 69.05 & 93.84 & 1.99 & 1.47 \\
\hline \multirow{2}{*}{ Activation of Plate } & $-2 \mathrm{~min}$ & 79.02 & 115.97 & 1.97 & 1.97 \\
\hline \multirow{2}{*}{ Duration of saturation } & $+2 \mathrm{~min}$ & 92.56 & 108.33 & 1.91 & 1.40 \\
\hline \multirow{2}{*}{ Development distance } & $-5 \mathrm{~min}$ & 72.86 & 74.61 & 0.86 & 1.28 \\
\cline { 2 - 6 } & $+5 \mathrm{~min}$ & 71.59 & 62.35 & 0.84 & 1.17 \\
\hline
\end{tabular}

Table 4: Robustness.

\section{Robustness}

Robustness of the method was studied by calculated the standard deviation of peak area for each parameter and \% relative standard deviation was found to be less than $2 \%$. Values of \%RSD are indicated in Table 4.

\section{Conclusion}

NP and B have been developed for the identification and quantification of Felodipine in bulk and pharmaceutical formulation. The method for the estimation of Felodipine was simple, accurate, precise, specific and selective. The methods were found to be linear in the concentration range of 300-1800 and 500$3000 \mathrm{ng} / \mathrm{spot}$, respectively. The method was validated as per ICH guidelines.

\section{Acknowledgment}

The authors are thankful to the principal, R. C. Patel Institute of Pharmaceutical Education \& Research, Shirpur. 425405 (MS), India, for providing the laboratory facility.

\section{References}

1. O'Neil MJ (2006) The Merck Index: an encyclopedia of chemicals. Merck and Co. Inc., USA.

2. Jadhav NR, Kambar RS, Nadaf SJ (2014) Dual wavelength spectrophotometric method for simultaneous estimation of atorvastatin calcium and felodipine from tablet dosage form. Adv Chem 2014: 1-6.
3. Mohamed W, Fathalla B, Nahed E, Sahar Z (2014) Micellar liquid chromatographic determination of felodipine in tablets and human plasma with fluorescence detection: Application to stability studies and content uniformity testing. Anal Methods 6: 3401-3409.

4. Martin A (2002) Determination of felodipine in plasma by capillary gas chromatography with electron capture detection. J Pharm Biomed Anal 2: 519526 .

5. Cardoza RM, Amin PD (2001) A stability indicating LC method for Felodipine. J Pharm Biomed Anal 27: 711-718.

6. Dhale C, Joshi S, Shete S (2014) Development and validation RP-HPLC method for analysis of Felodipine in bulk and pharmaceutical dosage form. Int Res J Pharm 5: 770-772.

7. Hesham S, Ola MA (2007) Determination of metoprolol and felodipine in binary mixture usning chemometric-assisted spectrophotometric and high performance liquid chromatographic-UV method. Am J Appl Sci 4: 709-717.

8. Basavaiah K, Chandrashekhar U, Prameela HC (2003) Detrmination of felodipine in bulk drug and in tablets by high performance liquid chromatography. Indian J chem Technol 10: 454-456.

9. Annapurna MM, Kumar BS, Goutam SVS (2013) Stability-indicating RP-HPLC method for determination of felodipine (A calcium channel blocker) in tablets. Indo Am J Pharm Sci 3: 9277-9285.

10. Liandong H, Qiaofeng H, Na G (2013) A validated stability-indicating HPLC method for the determination of felodipine and its related substances. Int $J$ Pharm Sci Res 4: 3369-3374.

11. Mohamed W, Fathalla B, Nahed E, Sahar Z (2014) Micellar liquid chromatographic determination of felodipine in tablets and human plasma with fluorescence detection: Application to stability studies and content uniformity testing. Anal Methods 6: 3401-3409. 
Citation: Jain PS, Ansari NA, Surana SJ (2018) HPTLC and RP-HPTLC Method Development and Validation for the Estimation of Felodipine in Bulk and Pharmaceutical Formulation. Pharm Anal Acta 9: 599. doi: 10.4172/2153-2435.1000599

Page 6 of 6

12. Sreedevi V, Kumar PR, Thatavarti R (2011) LC-MS method development and validation for the estimation of felodipine in human plasma and stability studies of freeze thaw analyte. Int J Pharma Sci Res 2: 65-73.

13. Akash AV, Pawar SS, Pande VV, Arote SR, Musmade DS (2015) Development and validation of UV spectrophotometric method for estimation of regioisomeric impurity in felodipine bulk and formulation. Int J Pharm chem 5: 128-133.

14. Alexandra FN, loana CC, Angela N (2016) The assay of felodipine by second derivative spectrophotometry. Farmacia 64: 143-146.
15. Nimje HM, Oswal RJ, Kshirsagar SS, Chavan M (2011) Spectrophotometric analysis for estimation of felodipine in tablet dosage form by calibration curve method. Res J Pharm Technol 4: 1805-1806.

16. Pandey MM, Charde SY, Jaipal A, Raut PP, Goel P, et al. (2017) Development and validation of simple high performance liquid chromatography methof for estimation of felodipine in rabbit plasma: Application to pharmacokinetic study. Curr Pharm Anal 13: 321-327.

17. Palem CR, Gannu R, Yamsani SK, Yamsani VV, Yamsani MR (2011) Development of high performance liquid chromatography method for simultaneous determination of pioglitazone and felodipine in pig serum: Application tompharmacokinetic study. Biomed Chromatogr 25: 952-958. 